\title{
Formation of partnerships among young women and men in Pune district, Maharashtra
}

Population Council

Follow this and additional works at: https://knowledgecommons.popcouncil.org/departments_sbsr-pgy

Part of the Demography, Population, and Ecology Commons, Family, Life Course, and Society Commons, Gender and Sexuality Commons, and the International Public Health Commons How does access to this work benefit you? Let us know!

\section{Recommended Citation}

"Formation of partnerships among young women and men in Pune district, Maharashtra," update. New Delhi: Population Council, 2006. 


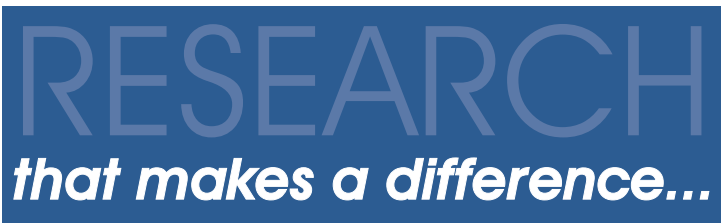

\section{FORMATION OF PARTNERSHIPS AMONG YOUNG WOMEN AND MEN IN PUNE DISTRICT, MAHARASHTRA}

\section{Background}

Aside from their educational attainment, economic activity levels and age at marriage, little is known about the lives of young people in India, especially the extent to which and the contexts in which they form romantic, marital and other partnerships or the nature of these partnerships. At a time when India's youth policy and reproductive and child health programmes have acknowledged the need to focus on youth, it is central that these gaps in understanding are filled. In this context, the KEM Hospital Research Centre and the Population Council conducted a study in Maharashtra in 2003-05 to obtain information on romantic and sexual partnership formation and sexual activity among young people (aged 15-24) through a large-scale community-based survey and related textual data gathering.

\section{Description of Project}

Data were collected from two sites, a rural and an urban slum setting, in Pune district, Maharashtra. Pune is one of the most economically and socially developed districts of Maharashtra, whose youth have greater access to education, employment opportunities and modern lifestyles than those in most other districts. Pune is one of six high HIV prevalence districts in Maharashtra.

The study examined the formation and experiences of partnerships among young women and men, including romantic and casual, pre-marital and marital, with and without physical and sexual contact. In order to better understand the context in which young people live, the study explored young people's own capabilities, notably their decision-making authority, perceptions of selfworth, mobility, gender role attitudes and awareness about sexual and reproductive matters, as well as their family relations and social networks.

A cross-sectional study was conducted amongst married and unmarried males and females in both the rural and urban study sites. The study design included a pre-survey qualitative phase that explored norms and experiences; a survey of 8,595 young people; and a post-survey qualitative phase in which selected survey respondents were interviewed in depth to better understand their experiences.

\section{Findings}

Findings confirm that while gender disparities in schooling patterns are narrowing, young people's lives continue to be defined by their sex, and to a lesser extent their area of residence and marital status. At the individual level, young men appear to have more control over their lives than young women do; young women however, are more likely to report egalitarian gender role attitudes. Awareness of sexual and reproductive health matters is far from universal; however, young men are more likely to be aware of condoms than are young 
women. Gender differences in such lifestyle indicators as substance use and exposure to pornographic films are wide, with young men far more likely than young women to report them. Evidence on parental connections and social networks suggests that many young people perceive their upbringing to be strict and family life to be characterised by little or no discussion of sexual and reproductive matters, domestic violence and paternal alcohol use. In contrast, the peer network plays a significant supportive role with regard to personal matters.

Opportunities for the formation of pre-marital romantic and sexual partnerships do exist in this outwardly traditional setting. Significant minorities of young men and women report involvement in a romantic partnership, despite close parental supervision. Gender differences in reporting of romantic experiences are considerable. Where such partnerships occur, they are initiated at an early age and where young couples spend time together, it is usually clandestinely. Among those who do initiate sexual relations, first sex occurs within a month of partnership formation for a significant minority. While sex with a romantic partner characterises the lives of the majority of the sexually experienced, findings suggest that young men, but not young women, also engage in sexual relations in other contexts, largely with sex workers. In total, some one in five young men and fewer than one in twenty young women have engaged in pre-marital sex. Multiple partner sex and inconsistent condom use are reported by many, and unwanted sex characterise the relations of notable minorities.

For the large majority of young people however, partnerships are formed within the context of marriage. Large proportions of women and men were married before the legal minimum age at marriage (18 for females and 21 for males). The overwhelming majority of marriages are arranged and few young people, especially young women, are effectively involved in marriage-related decisions. While most young people are satisfied with these arranged unions, many feel they were married at too young an age. Adjusting to new marriages is especially difficult for young women. These women report low levels of communication with their spouse and marital family early in marriage and limited control over material resources and family decisionmaking; a disturbing minority also report the experience of sexual coercion and domestic violence. Exercise of choice in the area of contraception and childbearing is also limited for both young women and men, underscoring the strong social norms that demand a pregnancy as soon as possible after marriage and that link fertility with a woman's security in her marital home. Pregnancy follows close on the heels of marriage and while significant minorities of young people wanted to delay the first pregnancy, no more than a small minority succeeded in practising contraception to postpone the first birth.

\section{Implications for Programmes}

Findings argue that it is time to shed traditional misconceptions about the rarity of pre-marital partnership formation or sexual activity among young people. Significant and multiple steps are needed. Sexuality education must be universalised; attention must be paid to build skills and agency among young women and promote new concepts of masculinity and femininity among youth more generally; and programmes must be developed that address parental inhibitions and encourage greater openness and interaction between parents and children. Equally important is the need for India's reproductive health programmes to be inclusive of unmarried young people and recognise their right to information and services on the one hand, and the unique needs of newly married young couples, on the other. In sum, findings argue for services and programmes that enable both unmarried and married youth to make their partnerships safe, wanted and informed.
12 Population Council

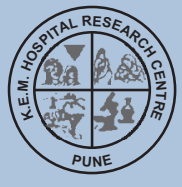

For further information please contact:

Population Council

Zone 5A, Ground Floor

India Habitat Centre, Lodi Road

New Delhi - 110 003, INDIA

Tel: 91-11-2461 2901/02

Fax: 91-11-2464 2903

Email: info-india@popcouncil.org

\section{www.popcouncil.org}

Mallika Alexander, Laila Garda, Savita Kanade (KEM Hospital

Research Centre);

Shireen J. Jejeebhoy (Population Council); Bela Ganatra(Ipas)

\section{Donors}

The William and Flora Hewlett Foundation,

The John D. and Catherine T.

MacArthur Foundation

\section{Reference}

Alexander, M., L. Garda, S. Kanade et al. 2006. Formation of partnerships among young women and men in Pune district, Maharashtra, Research Report. New Delhi: Population Council. 